\title{
Pliocene-Quaternary stratigraphy and sedimentation at the Neretva River Mouth, on Croatian Adriatic Coast
}

\author{
Davorin BALIĆ ${ }^{1, *}$ and Tomislav MALVIĆ ${ }^{1,2}$ \\ 1 INA-Industry of Oil Plc., Šubićeva 29, 10000 Zagreb, Croatia \\ 2 Faculty of Mining, Geology and Petroleum Engineering, Pierottijeva 6, Zagreb, Croatia
}

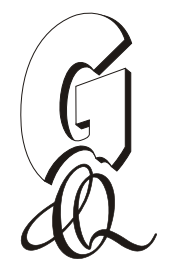

Balić D. and Malvić T. (2013) Pliocene-Quaternary stratigraphy and sedimentation at the Neretva River Mouth, on the Croatian Adriatic Coast. Geological Quarterly, 57 (2): 233-241, doi: 10.7306/gq.1090

\begin{abstract}
The Adriatic Sea is an epicontinental, closed sea, part of the Mediterranean. It formed in the Late Miocene, and ended structurally during the Pliocene and Quaternary, when most of its sediments were deposited. The larger Pliocene and Quaternary depressions occur mostly by the western coast, where the deposits are several thousand metres thick, and were sourced from the Alps and the Apennines. The east coast is characterized by the large and elongated Dinarides Mts., that have continental drainage extremely close to the shoreline and a very small erosional rate. Consequently, eastern inflows were and are very short, including strongly tidal estuaries that erode only small volumes of mostly carbonate detritus, adjacent to frontal islands or mountains, with restricted depositional areas. The Neretva River deposits make up part of the largest contemporary delta system on the eastern Adriatic coast, and have been analysed in this study using three seismic sections and one exploration borehole. These deposits are recognized inside the Neretva and Korčula channels, assuming that processes operating during Quaternary glacial phases shifted the delta tens of kilometres to the west in the past on several occasions.
\end{abstract}

Key words: Adriatic, Neretva, delta, clastics, Pliocene, Quaternary.

\section{INTRODUCTION}

Recent sedimentation and distribution of sediments in the Adriatic Basin can help to reconstruct the overall history of basin formation and infill. It is a relatively young basin, created in the very Late Miocene (Messinian) and continuously evolved during the Pliocene and Quaternary, being filled with clastic sediments with at least six sea level changes recognized through the Quaternary. The term "Adriatic Basin" (considered a depression, or better depressional system) includes, generally, the Adriatic Sea and the inland part of the Po Depression, and is surrounded by the massifs of the Southern Alps, Dinarides and Apennines. These orogens are the sources of the clastic materials deposited during the Late Miocene, Pliocene and Quaternary, but are of different importance due to their palaeomorphology, altitude, length of their river systems and the transported volumes of terrigenous clastic deposits.

Fluvial sediment today transported into the Adriatic Basin comes from the western coast. Much has come from the north-west, i.e. from the Alpine hinterland of the Po and Veneto depressions, being transported by the Po, Adige, Piave and other, smaller, river systems (encompassing delta and pro-delta

\footnotetext{
* Corresponding author: davorin.balic@ina.hr
}

Received: October 25, 2012; accepted: December 7, 2012; first published online: April 29, 2013 environments). However, the main source of sediment is the Apennine Mts. This area has significantly shorter and weaker, but more numerous, river systems than the Alpine region, which dominantly filled the Marche-Abruzzi or Bradano depressions at the western coast. Cattaneo et al. (2003), Frignani et al. (1992), Milliman and Syvitski (1992) and Sorgente (1999) reported that on the western coast the sediment supply from eastern Alpine rivers is $3 \times 10^{6} \mathrm{t} / \mathrm{yr}$, from the Po River $15 \times 10^{6} \mathrm{t} / \mathrm{yr}$; eastern Apennine rivers north of the Gargano promontory deliver $32.2 \times$ $10^{6} \mathrm{t} / \mathrm{yr}$, and only $1.5 \times 10^{6} \mathrm{t} / \mathrm{yr}$ south of that promontory.

Minor sources are the river systems and depositional environments located at the eastern coast. Their transport of sediment is negligible when compared to the systems in the west, which also filled the Croatian part of the Po Depression with silty and some sandy detritus (e.g., Velić and Malvić, 2011). The sediment load of the eastern systems has not yet been calculated, but probably can be compared in magnitude similar to the smallest ones on the western coast, i.e. river systems south of the Gargano promontory. This is why the eastern systems can be regionally studied only via the examples of the large ones, and the Neretva River was probably the largest fluvial system on the eastern coast during the Pliocene and Quaternary.

Very little clastic deposition occurred on the eastern deltas due to the lithology of the rocks in the hinterland (mountains), which are almost entirely composed of Mesozoic and Paleogene hard rocks belonging to the Adriatic Carbonate Platform (AdCP; e.g., Vlahović et al., 2005), slightly weathered and covered with very thin soil. It may be supposed that the eastern rivers have been very short from the Pliocene to recent times due to the location of the continental drainage line (Fig. 1), 


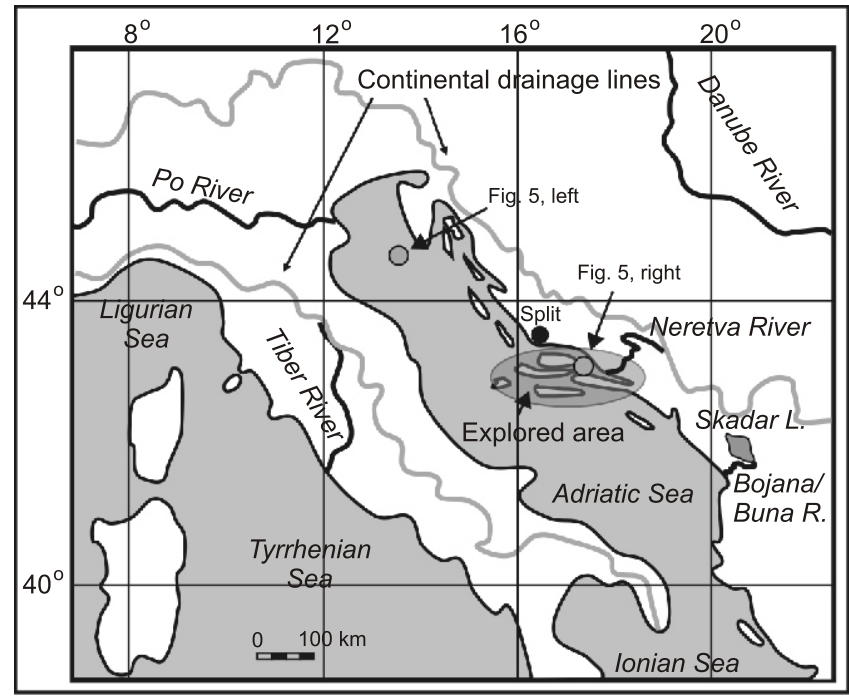

Fig. 1. Regional drainage lines around the Adriatic Sea showing the largest rivers

which is only a short distance, of a few to a few tens of kilometres, from the eastern coast of the Adriatic Sea. Also, almost all the rivers on the eastern coast have tidally dominated deltas, i.e. estuaries such as the Raša River in Istra where clay detritus dominates (e.g., Sondi et al., 1995) or the Krka River near Šibenik in Middle Dalmatia (e.g., Cukrov et al., 2010).

\section{EVOLUTION OF THE ADRIATIC SEA AND IMPORTANCE OF THE NERETVA RIVER DEPOSITIONAL AREA}

The Adriatic Sea is formed on the basement of the Adriatic microplate. The separation of this microplate from the African macroplate occurred from the Middle Triassic to the Middle Jurassic, and characteristic carbonate platform sedimentation existed in the AdCP to the end of the Late Cretaceous (e.g., Vlahović et al., 2005). During the Paleogene, in some areas, sedimentation of carbonates continued on existing platforms. Mesozoic carbonate platform, and later carbonate, sediments can be found on the Adriatic Sea basement, offshore of the Adriatic islands, but also onshore in the Dinarides and Southern Alps. The Paleogene is characterized by the disintegration of the AdCP and the uplifting and forming of the Alps and Apennines. The end of the Miocene glacial period in the Antarctic area caused global sea levels to decrease by about $50 \mathrm{~m}$. This caused the connection through to Gibraltar to be interrupted, and the Mediterranean was mostly divided into shallow environments, where large quantities of evaporites were deposited, as also shown in the Adriatic Sea (Veseli, 1999). After the Messinian salinity crisis, the contemporary shape of the Adriatic Basin began to be established around the Middle Adriatic horst, with significant volumes of siliciclastics being transported, especially from Alpine regions. The thickest Pliocene and Quaternary deposits in the Adriatic Basin are documented in the Po Depression, reaching approximately 6 kilometres or more. Sediment distribution was influenced by regional transpression and uplift, as well as by Quaternary glacials. Generally, during the Pliocene and Quaternary, sea level oscillations and delta progradations caused enormous quantities of clastics were transported into the Adriatic Basin, accumulating within several Miocene and Pliocene-Quaternary depressions

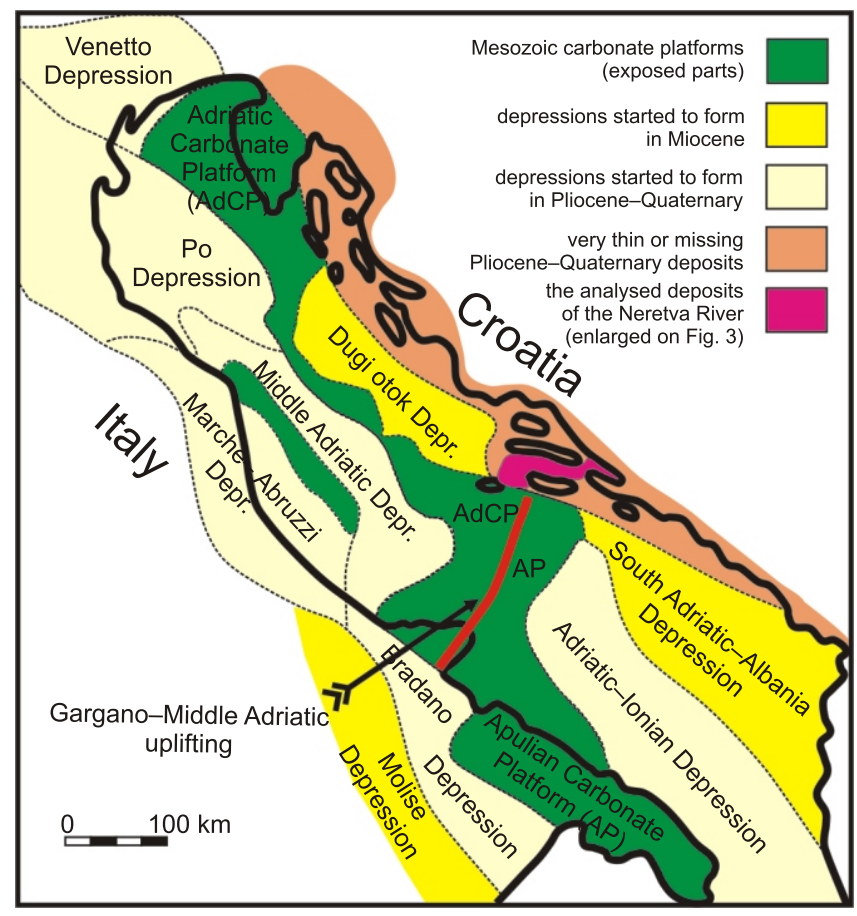

Fig. 2. Miocene and Pliocene-Quaternary depressions in the Adriatic Basin (modified after Velić and Malvić, 2011)

(Fig. 2). In the Early Pliocene, sea level in the Adriatic was higher than it is today, and marine environments covered a much larger area, i.e. approximately the entire contemporary Adriatic Basin. This has been shown by the presence of marine Pliocene strata in the Northern Apennines and the palaeodelta of the Po River (Velić, 2007). In the Croatian part of the Northern Adriatic, planktonic and benthic foraminifera have confirmed the presence of a marine environment, indicating a warm climate and sedimentation on an outer shelf (Thunel, 1971). In the Late Pliocene, the number of species became reduced. Planktonic foraminifera (Kalac, 2008) from the epibathyal zone at 600-1000 m depth dominated, mostly on the western coast, where down warping was rapid, reflected by the deposition of large quantities of organic matter (Rio et al., 1997). The climate changed from warm to moderately cold. During the Quaternary significant climate changes occurred, alternating between warm and cold conditions. Consequently, in glacial periods, marine environments decreased in area, especially in intra-island areas. This also took place in the area analysed which in the last glacial phase was exposed as land.

Consequently, sandy and silty sediments, dominantly turbiditic, prevail in the Veneto, Po, Middle Adriatic, March-Abruzzi, Bradano and Adriatic-Ionian depressions, which are also described as Pliocene-Quaternary depressions (e.g., Prelogović and Kranjec, 1983; Velić and Malvić, 2011). Such sand and mud sedimentation in palaeoriver systems (i.e., deltas and prodeltas) was interrupted by the hemipelagic basinal deposition of clay and carbonate. The majority of terrigenous were transported and deposited from alpine regions, by the streams, deltas and prodeltas of the Po, Adige and Piave rivers, into the Po and Veneto depressions. Several smaller deltas from the Apennines extended into the Marche-Abruzzi and Bradano depressions, but there was little or no terrigenous siliciclastic sedimentation along the eastern coast (Fig. 2).

Present-day fluvial sedimentation along the eastern coast is localized in smaller deltas or estuaries, and is constrained by 


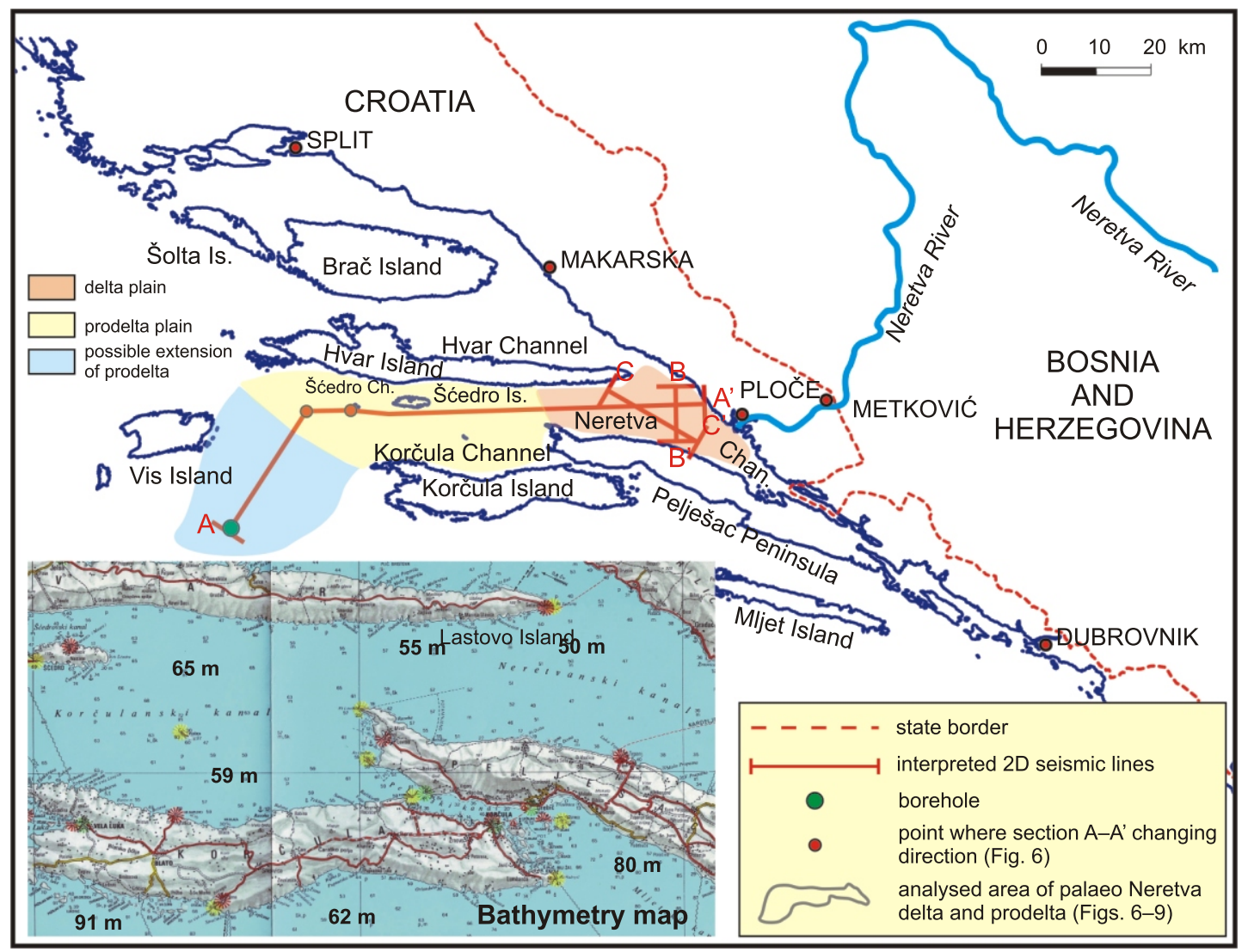

Fig. 3. The location of delta of the Neretva River and 2D seismic lines analysed

geomorphology. Only from the Bojana (in Albanian Bunë or Buna) River (Fig. 1), at the Albanian coast, has a delta extended into the open littoral area belonging to the South Adriatic-Albania Depression. The Neretva River (Fig. 3) is the largest siliciclastic depositional system on the eastern coast. It has a length of $225 \mathrm{~km}$, and the area of the delta is approx. $170 \mathrm{~km}^{2}$, which is also considered as an estuary due to the strong tidal influence. Brackish water reaches upstream (Gotovac et al., 2003) as far as the town of Metković (Fig. 3), which is about $20 \mathrm{~km}$ from the mouth of the river (the location of "Stari most" is traditionally the boundary between fresh and brackish water).

Based on previous research on the influence of Quaternary glacials on shifting coastlines (Fig. 4), and glacier extensions into the eastern Adriatic (e.g., Colantoni et al., 1979; Correggiari et al., 1996; Kalac, 2008; Velić and Malvić, 2011; Velić et al., 2011), the Neretva palaeo-prodelta is known to have possibly reached the distant part of the Korčula Channel (Fig. 3), i.e. sediments of the delta and prodelta should be assumed as being also in the area of the Neretva, Korčula and Sćedro channels (Fig. 3). The Pelješac Peninsula had remarkable influence on the Neretva sediments, especially through interglacials as well as today (Fig. 3), directing flow from the Neretva River mouth. The general shape of seismic reflections analysed seismic reflexes directly reflect of eustatic changes during interglacial and glacial phases. According to the schematic model of Adams et al. (2001), the mostly overlying reflections indicate prograding deltas where fluctuation in base level exceeds progradation rates, resulting in sigmoidal profiles. This is the best evidence in the areas analysed of glacial influence on eustatic oscillations during the Quaternary and progradation of the locus of river deposition (Würm, Fig. 4A; Early Holocene, Fig. 4B).

\section{INPUT DATA AND ANALYTICAL METHODS}

The study area covers about $1500 \mathrm{~km}^{2}$ and has been primarily analysed using seismic interpretation of three selected sections and one borehole, located approx. $90 \mathrm{~km}$ west from the mouth of the Neretva River (Fig. 3). The sections selected were chosen from 10 available interpreted sections (in the archive of INA-Industry of Oil Plc.; also publicly presented by the authors in 2011 as a poster "First insights about Pliocene-Quaternary sedimentation in Neretva River palaeodelta" at the 1st Central and Eastern European international Oil and Gas conference and exhibition, held in Siofok, Hungary) along the area explored. The selection was made using three criteria: (a) a clearly recognized regional seismic boundary between the Mesozoic and Cenozoic, (b) clear seismic reflections in the Cenozoic, (c) the sections selected were arranged approximately transverse and perpendicular to the depositional area analysed, i.e. indicating probable progradation. The seismic correlation included significant uncertainty due to the limited number of boreholes and time-marker horizons. The youngest interpreted well e-log marker was the boundary between the Mesozoic and Cenozoic rocks. Moreover, the Adriatic Basin formed after the Miocene, so the Cenozoic sedimentary sequence is of Pliocene and Quaternary age. These Pliocene-Quaternary deposits have not yet been the subject of petroleum exploration in the Croatian part of the Middle Adriatic.

The Pliocene-Quaternary deposits analysed offshore (part of the Middle Dalmatia region) are thin. However, the regional lithostratigraphy of the area analysed has been correlated with units published by Velić and Malvić (2011). The same lithostratigraphic formations from the Croatian part of the Po 

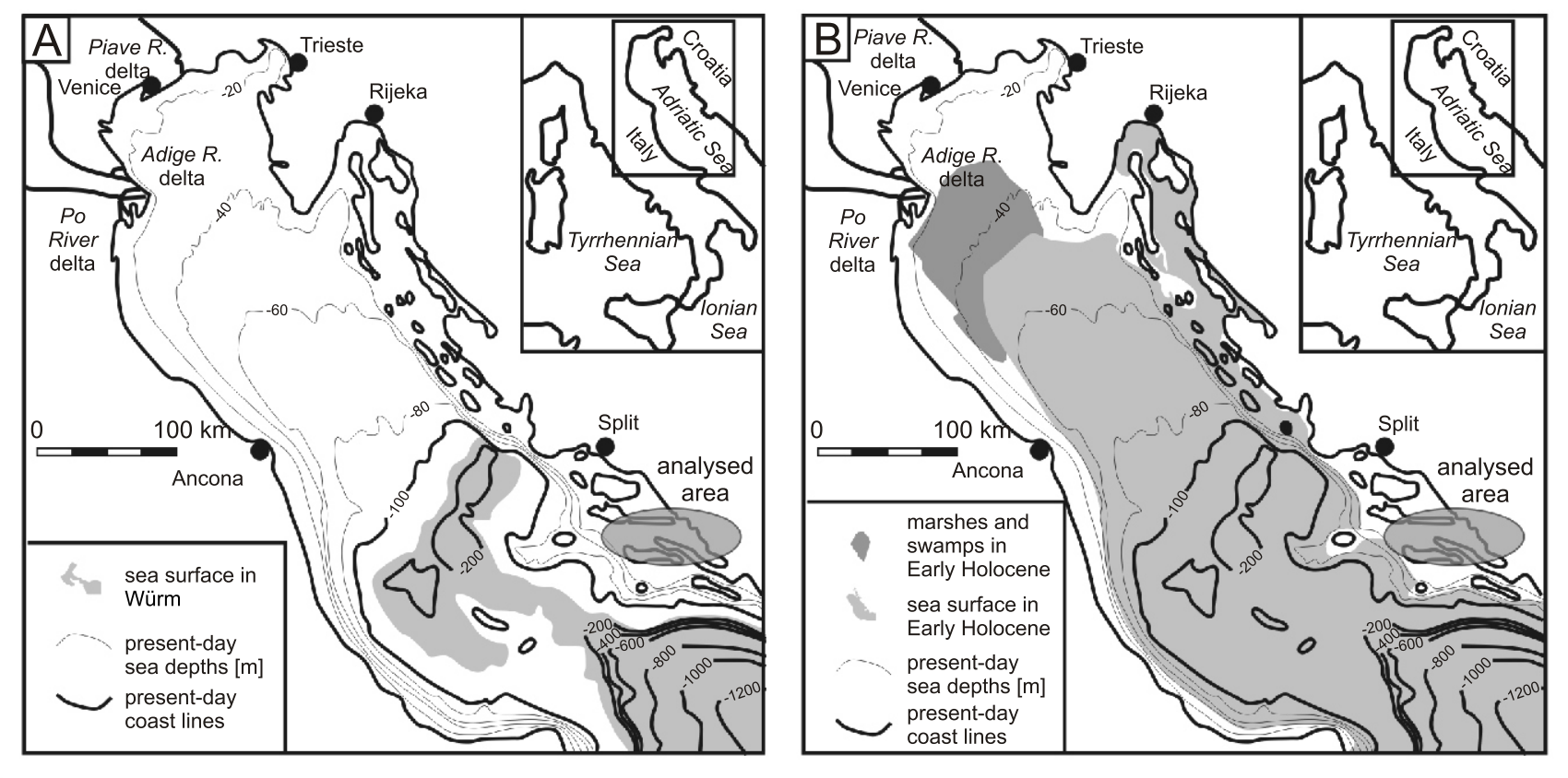

Fig. 4A - borders of the Adriatic Sea during the Würm; B - Early Holocene (modified after Corregiari et al., 1996; Velić and Malvić, 2011)

Depression can also be assumed to be present in the Neretva offshore river system (Fig. 5) because, until now, the depositional system and consequent lithostratigraphy inside the Dugi Otok Depression or the Pliocene-Quaternary deposits over the AdCP (Fig. 2) have not been investigated in the area analysed.

The purpose of all regional exploration in the past has been to observe the possible accumulation of hydrocarbons, so seismic data has been processed to emphasize the signals from Mesozoic rocks, where such discoveries are expected. However, Mesozoic carbonates, due to possessing highly faulted and fractured zones, are unfavourable media for seismic reflection, especially in their deeper parts. Most of the noise and multiples were removed during seismic processing but some fake reflections, low vertical resolution and "ghost" structures can still be observed on Figures 6-8. The secondary tool corresponded with results obtained in Pliocene-Quaternary strata from a borehole in the Northern Adriatic, explored due to the presence of numerous gas reservoirs.

\section{RESULTS OF SEISMIC INTERPRETATION}

The positions of the three selected interpreted seismic sections are shown on Figure 3 . The section $A-A^{\prime}$ is approximately $100 \mathrm{~km}$ long, with several points where section strike had been changed. Its length reflects the need to seismically follow the section through both the Neretva and Korčula channels, i.e. in this case along (possible) sediments of the Neretva River, confirming the readings with the closest available offshore borehole. However, that borehole is located outside the Korčula Channel in a possible prodelta environment and was the only available well location in the close neighbourhood of the area analysed. Only e-log border depths are publicly available presently, and consequently were used in the analysis presented. The next two sections, B-B' and C-C', are located entirely in- side the Neretva Channel, i.e. they are assumed to cut the deposits of the Neretva River palaeo-delta. The section B-B' is oblique to the channel strike, and section $C-C^{\prime}$ is transverse to it (Fig. 3), giving good insight into seismic reflection forms (such is overlapping and overlying). All three seismic sections have been interpreted in a time scale, using well-based, time-depth conversion techniques. However, the "top of carbonate" marker between the Pliocene and Mesozoic strata is relatively shallow, so the conversion ratio can be assumed to be $1(1 \mathrm{~ms}=$ 1 metre) for the entire Pliocene-Quaternary interval. However, it was not possible to outline any single e-log marker younger that the top of the Mesozoic.

The interpretation of the longest seismic section A-A' (Fig. 6) showed that there is no significant difference in the thickness of Pliocene-Quaternary deposits from the western part of the Neretva Channel to the western margin of the Korčula Channel (the position of the seismic section A-A' is shown in Figure 3, as well as the positions of the other two seismic sections). It depicts shallow bathymetry during the entire Pliocene-Quaternary interval, influenced mostly by numerous glacial phases that strongly reduced the extension of the Adriatic Sea in general (e.g., Correggiari et al., 1996; also referred to in Velić and Malvić, 2011).

The Mesozoic basement had a major influence on the Pliocene heritage structures, continuing almost to the top of the Quaternary. This is why basement features (e.g., "buried hills") have been used as the main criterion for delineation between delta and prodelta plains (Figs. 3 and 6). These "features" were uplifted forms during the entire Pliocene and Quaternary and geomorphologically they were places that decreased the flow velocities of any streams that came from E/NE, i.e. the Neretva River mouth in the past. Consequently, such "barriers" decreased current speed, causing deposition of suspended detritus, and reducing the volume of sand and silt in suspension.

Furthermore, there are no interpretable unconformities in the PI-Q interval, except to the top of the Mesozoic (marked as "top carbonates" on Figs. 6-8). All fault zones show dis- 
Northern Adriatic; Croatian part (Po Depression; Velić and Malvić, 2011)

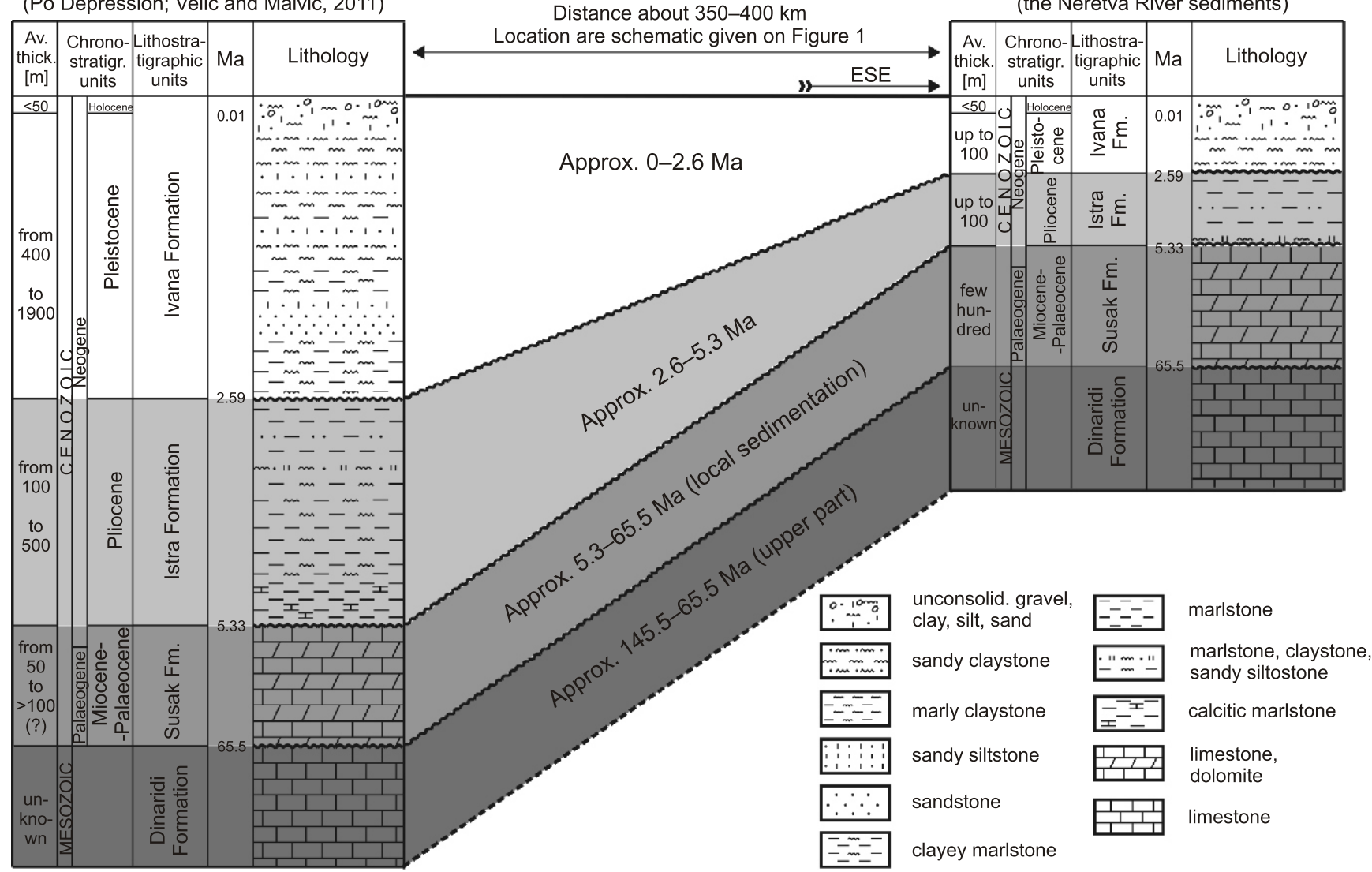

Fig. 5. Comparison of relative thicknesses of lithostratigraphic formations in the northern Adriatic Sea and in the Neretva River delta

The regional distribution of different environments is shown on Figure 3

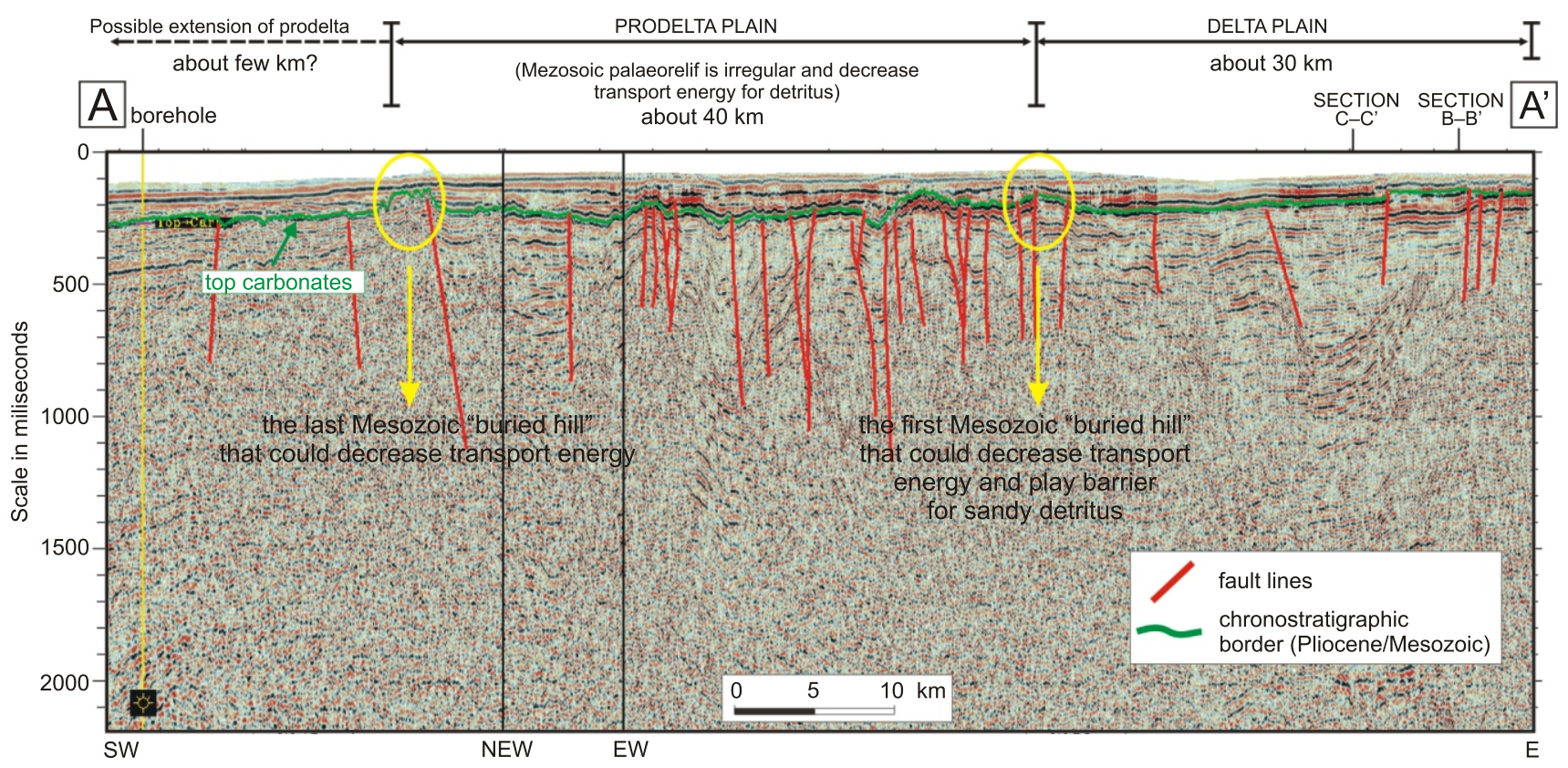

Fig. 6. Interpreted composite seismic section A-A' (time domain) 


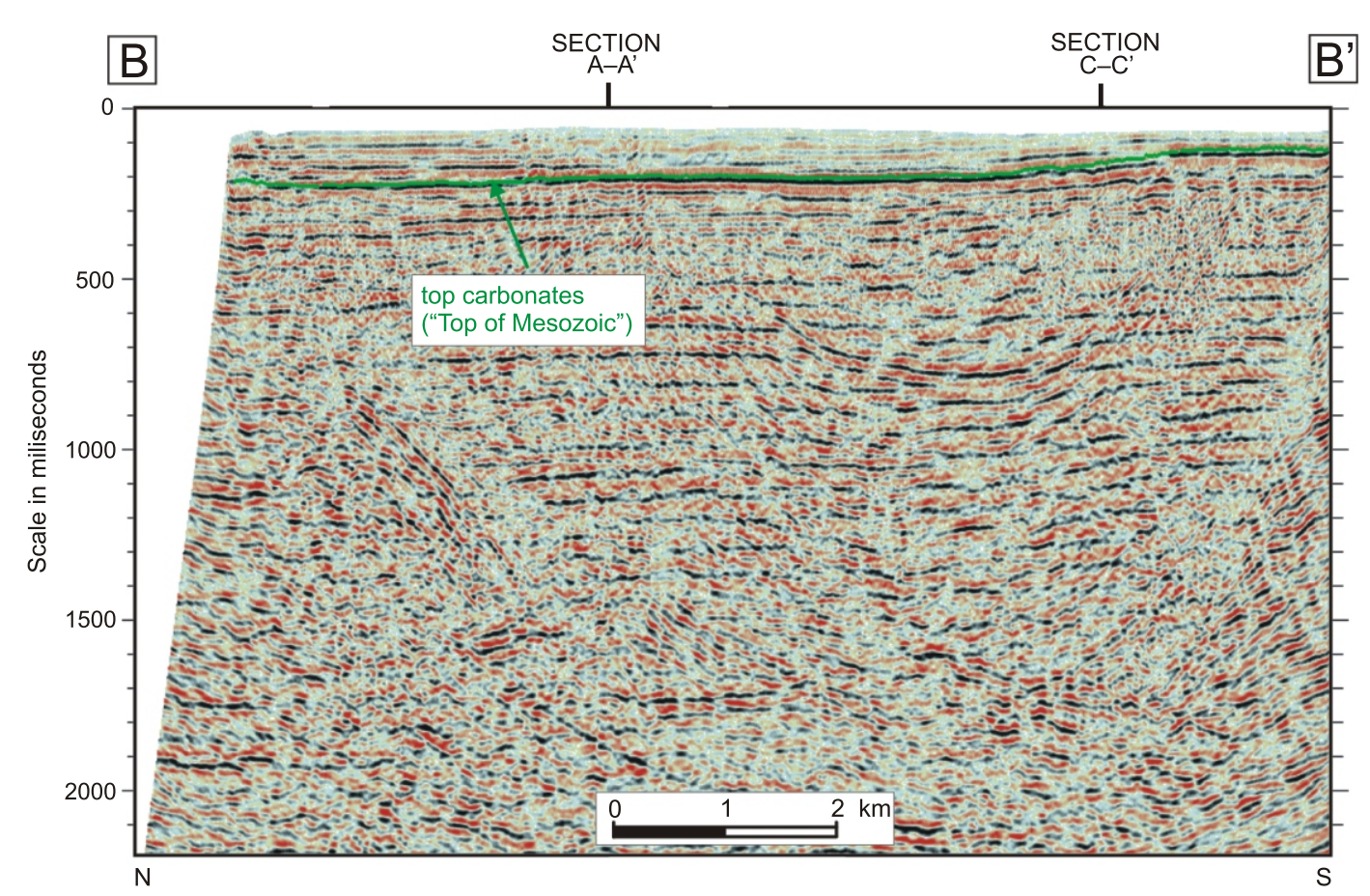

Fig. 7. Interpreted seismic section B-B' (time domain)

Explanations as in Figure 6

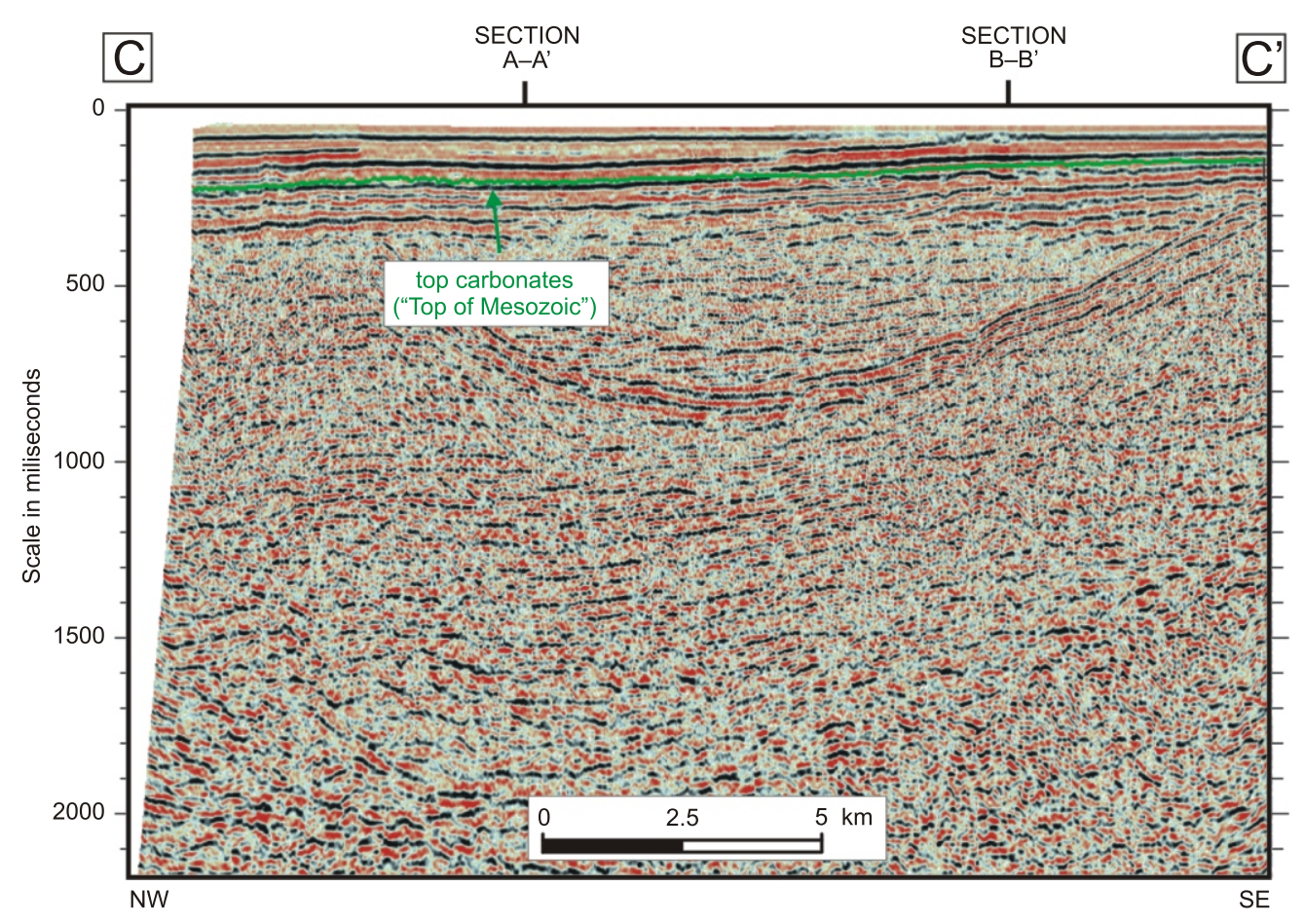

Fig. 8. Interpreted seismic section C-C' (time domain)

Explanations as in Figure 6 
placement in the Mesozoic, but only a few have faulted the oldest Pliocene deposits (sections B-B' and C-C'). Using the basement palaeogeomorphological features, on the transverse section $A-A^{\prime}$ for $25-30 \mathrm{~km}$ there are deposits that are very likely delta deposits (Fig. 6), and along the next 35-40 km of the prodelta (Fig. 6). How the depositional environment interpretation relates to Mesozoic relief forms, the extent of the prodelta can be only inferred using the last seismically recognized Mesozoic forms that are an extension of the Korčula Island structure.

The section B-B' (Fig. 7) is located approximately perpendicular (Fig. 3) to the contemporary delta of the Neretva River. The Pliocene-Quaternary syncline with maximum stratal thickness can be easily observed in the middle of the Neretva Channel.

Section C-C' (Fig. 8) is located obliquely to the Neretva Channel (Fig. 3) and shows that thicknesses increase towards the Hvar Island. Using the section A-A' interpretation of the prodelta, those reflections on $\mathrm{C}-\mathrm{C}^{\prime}$ belong to a delta environment. The direction of sediment transport and progradation can be clearly set from SE to NW.

\section{DISCUSSION}

The main topic of discussion, from the analysis above, is the age of inferred Pliocene and Quaternary strata in the Neretva and the Korčula channels. The Adriatic Sea started to form as a contemporary basin after the Messinian salinity crisis, i.e. during the Pliocene (5.332-2.588 Ma) and Quaternary (2.588-0 Ma). At the end of the Messinian, the link between the Mediterranean and the Atlantic was re-established and a new sedimentation cycle began in the shallower parts of the Adriatic Basin. This is why it is assumed that the age of the Neretva River deposits is restricted only to the Pliocene and the Quaternary, but their inception is impossible to determine from available data in this moment.

The present analysis is based on a relatively small number of datasets, specifically from one borehole and three seismic sections, which are considered the most representative, publically available through previous publications (Balić and Malvić, 2011) and shown in this paper. The seismic sections cover an explored area that belongs to the Neretva River offshore river system in the Pliocene and the Quaternary. Unfortunately, only one offshore borehole was available from which to select a chronostratigraphic marker and correlate regional seismic data and no core samples or formation tests have been performed when analysing post-Mesozoic strata. This study was only made possible by correlating the data with more extensive borehole data from Pliocene and Quaternary deposits collected in the Croatian part of the Northern Adriatic (Fig. 5), where the presence of large gas reservoirs has permitted extensive regional exploration in deposits of the Po Depression. Investigations performed in the hinterland of the Neretva River Mouth cannot give any insights into Pliocene-Quaternary ma- rine sedimentation, because there of mostly non-deposition or only local alluvial sedimentation. However, glacial deposits observed further to the west, at Velebit Mt., support the idea that Biokovo Mt. (above the town of Makarska, Fig. 3) was partially glacier-covered, when land extended across the area of the Neretva and Korčula channels towards the west (Fig. 4).

Because of sparse data, this research is restricted to the area of the Neretva and Korčula channels. Considering the geological and natural processes, one may suppose that sediments of the Neretva River once reached the Sćedro and Hvar channels (Fig. 3) and even the area of Vis Island, especially during the Würm when the shoreline shifted to the SW (Fig. 4A). Such an assumption may be tested in the future if new seismic data become available, or new boreholes are drilled. Also, new data could help to define the border between deltic and prodeltic environments of the Neretva River, which is difficult due to continuously shallow conditions during the Quaternary. According to present-day bathymetry, the depth of the Neretva and Korčula channels does not exceed 80 metres (Fig. 3). This means that a typical prodelta environment, unaffected by waves or tides and where mud and silt accumulate essentially from suspension, cannot be defined precisely.

Generally, on the Mediterranean and Black Sea margins, prodelta deposits are up to tens of metres thick, extensive, shore-parallel, and mud-dominated (Trincardi et al., 2004). When viewed on high-resolution reflection seismic profiles, prodelta environments are more complex, with subtle but important internal discontinuities and pinch-outs. Such features can be observed on seismic sections of many Holocene delta systems, as in the Po delta system where major accumulations of fine-grained sediments ( $>20 \mathrm{~m}$ thick) occur in the prodelta region (Trincardi et al., 2004). Numerous pinch-outs and downlaps along Mesozoic basement are also interpreted in the oldest Pliocene deposits of the Neretva River (Fig. 9).

In the Adriatic Sea, river offshore systems can be divided into two major groups with (a) rocky and (b) sandy hinterland. The main deltas are connected with sandy and silty detritus and large, onshore plains, such as the Po Plain, with the largest one. But, on the eastern coast, detritus is derived from rocky hinterland with small drainage areas. Such smaller, palaeogeographically limited Quaternary deltas are well studied around the world due to easily collection of samples and historical maps and records. Characteristically they give rise to transgressiveregressive deltaic sequences where sediments grade from coarse fluvial sand in the valley axis to fine estuarine mud. Interestingly, the main source of mud in the delta is also fluvial, as shown, e.g. by the example of the Holocene delta in the Lavaca-Garcetas River Valley in Central Texas (Wilkinson and Byrne, 1977), where fluvial discharge at the head of the delta comprised about three-quarters of the total mud contribution.

However, a subaqueous delta can be defined also as a wedge-shaped prograding body that may or may not be linked to a specific to "a specific source at the shoreline (a delta sensu stricto) and with relatively flat topset region occurring in variable

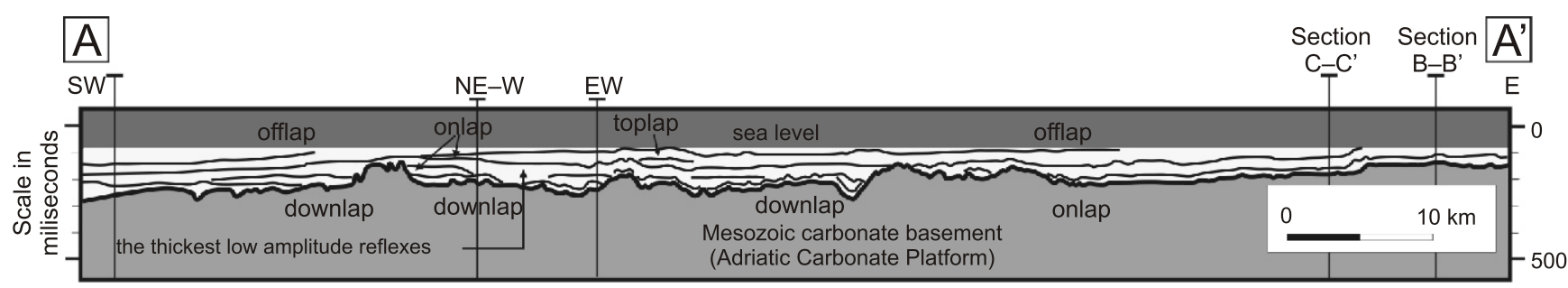

Fig. 9. Interpreted seismic stratigraphy in Pliocene-Pleistocene deposits (lapping forms) from the section A-A' 
water depths, depending on the limiting oceanographic regime" (Cattaneo et al., 2003). Such a subaqueous delta offshore is, e.g., limited to the Gargano promontory in the Central Adriatic, which is detached from any coastal plain and direct river supply. This typically produces a set of laterally continuous mud-dominated regressive wedges, up to several tens of metres in thickness. Such wedges are formed seawards of major deltas on Mediterranean margins after the recent sea level highstand during the mid-Late Holocene, i.e. the Late Pleistocene-Holocene (approx. 17,000 and 5500 year BC) sea level rise (Fairbanks, 1989), under the combined influence of fluvial supply and marine processes (Gensous et al., 1993; Correggiari et al., 2001; Cattaneo et al., 2003). Toplap is specific for such delta wedges, which are mostly formed in two Adriatic foreland basins at the western Adriatic coast. Toplap can be observed also on seismic sequences of the Neretva River (Fig. 9); however, the youngest Neretva sediments (Holocene?) mostly terminate upwards creating offlap structures. That results from prodelta progradation towards the deeper part of the sea (Figs. 6 and 9). The difference comes because large, offshore mud wedges are not characteristic of the eastern Adriatic coast due to the absence of a classical slope, shallow environment and a highly rugged coastline.

\section{IMPLICATIONS AND CONCLUSIONS}

This is one of the first seismic interpretations of the Pliocene-Quaternary strata on the eastern coast of the Adriatic Sea. Generally, the eastern river depositional systems have been regionally poorly explored with seismic lines and drilling, mostly because they are thin sequences without any economic significance as regards hydrocarbon accumulations. Here we show a seismic interpretation of the Neretva River deposits, which is considered to be the river with the largest delta on the eastern coast since the Early Pliocene.

The Neretva deposits can be easily followed on the seismic sections selected, as they comprise clear seismic reflections over the top of the Mesozoic. Only the Mesozoic-Pliocene boundary was regionally marked in the area analysed. It was hard to distinguish the extent of the Neretva delta and prodelta, mostly because of the thickness very gradually increasing, and entire bed sequences mostly overlying each other, without any characteristic seismic stratigraphic forms (such as onlap, offlap etc.). Also, the depositional area was too narrow to form lobes or shore parallel wedges, especially of a size that would be recognized on seismic sections.

However, if the present-day geomorphology changed slightly during the last $5 \mathrm{Ma}$, it may be assumed that the Neretva delta sediments have been continuously deposited inside the Neretva Channel, and prodelta sediments in the Korčula Channel. According to palaeogeographic reconstructions the depth of that area from Early Pliocene probably was not greater than 100 metres. Consequently, the influence of Quaternary glacials was very strong and extended land area tens or even hundreds of kilometres towards the South Adriatic abyssal plain. Generally, the Adriatic Sea has a very irregular bathymetry, with a very shallow northern part, and the maximum depth of $1233 \mathrm{~m}$ is located in the Southern Adriatic, i.e. Adriatic-Ionian Depression (Fig. 2). That the deepest part can be considered as typical abyssal plain, even with evidence of sand-silt layers interpreted as deep turbiditites (van Straaten, 1964). These sediments were likely derived from rivers located on the southwestern Adriatic coast. The present-day largest river system is the Buna/Bojana River on the Albanian/Montenegro coasts. Although its discharge extends northwards along the coast for approximately one hundred kilometres, as estimated from freshwater influence and chlorophyll concentrations (Marini et al., 2010), the present-day delta is not associated with such large volumes of detritus as are river systems along the western coast. This results from the rocky, carbonate Dinaric hinterland, with a low erosional rate. Such river systems on the southeastern coast of the Adriatic Sea can be easily compared with systems on the east coast, e.g., the Neretva River system. By contrast, river systems on the western coast are characterized by significantly larger distribution systems and abundant detritus in input.

The following may be concluded:

- sedimentation in river systems along the eastern and southeastern Adriatic coast is highly influenced by uplifted palaeogeography, as shown for the Neretva River system;

- the rocky, carbonate hinterland of the Dinaric Mountains has the low erosional rate;

- those mountains defined the continental drainage line very close to the coast, limiting the length of the river systems, in the present and in the past.

The analysis of the Neretva deposits also showed that the thickness of the Pliocene and Quaternary sequence rarely reachs 200 metres. The shape and thickness of Pliocene-Quaternary sequence was strongly influenced by the shape of the Mesozoic basement, especially during the Pliocene, from which time structures are inherited. Pliocene deposits are characterized as truncation along the basement, i.e. downlap and onlap forms (Fig. 9), a result of the highly faulted and locally significantly uplifted Mesozoic carbonates. By contrast, the Late Pleistocene and Holocene sequences of the Neretva River are flattened, and offlap only locally be recognized (Fig. 9) as a result of progradation towards west and south-west.

The further exploration of the Neretva and other river systems along the eastern coast will be connected with future projects for regional geological and hydrological exploration. Targets may be protection of freshwater sources in river deltas, regarding their importance for agricultural zones and natural wildlife parks. New drilling and seismic analysis of Pliocene and Quaternary sands and silts may be directed towards on proving possible hydrocarbon gas reservoirs, as proven in the Po and Venetto depressions. However, small thicknesses means that further petroleum research along the eastern coast will probably explore the Mesozoic basement rocks as possible targets for hydrocarbon systems in the Adriatic Sea.

Acknowledgements. The authors would like to thank reviewers Dr. B. Vrbanac, retired as expert for sedimentology in INA-Oil Industry Plc., Croatia, and Prof. Dr. J. Geiger, now Associate Professor in geomathematics and sedimentology at the University of Szeged, Hungary. Also, Prof. Dr. T. M. Peryt, the Editor-in-Chief of the Geological Quarterly journal, very patiently and carefully help us to deal with all reviewer and journal inquiries. 


\section{REFERENCES}

Adams E.W., Schlager W., Anselmetti F.S. (2001) Morphology and curvature of delta slopes in Swiss lakes: lessons for the interpretation of clinoforms in seismic data. Sedimentology, 48: 661-679.

Balić D., Malvić T. (2011) First insights about Pliocene-Quaternary sedimentation in Neretva River palaeodelta. The First Central and Eastern European International Oil and Gas Conference and Exibition (eds. A. Holoda, M. Zelić, A. sr. Osz, J. Križ), Abstracts: 125. MONTAN-PRESS Program Organizing, Consulting and Publishing Ltd., Budapest.

Cattaneo A., Correggiari A., Langone L., Trincardi F. (2003) The late-Holocene Gargano subaqueous delta, Adriatic shelf: sediment pathways and supply fluctuations. Marine Geology, 193: 61-91.

Colantoni P., Gallignani P., Lenaz R. (1979) Late Pleistocene and Holocene evolution of the North Adriatic Shelf (Italy). Marine Geology, 33: M41-M50.

Correggiari A., Roveri M., Trincardi F. (1996) Late Pleistocene and Holocene evolution of the North Adriatic Sea. Quaternario, 9 (2): 697-704.

Correggiari A., Trincardi F., Langone L., Roveri M. (2001) Styles of failure in heavily-sedimented highstand prodelta wedges on the Adriatic shelf. Journal of Sedimentary Research, 71: 218-236.

Cukrov N., Surić M., Fuček L., Ćosović V., Korbar T., Juračić M. (2010) Geology of Krka River estuary. Proceedings of 4th Croatian Geological Congress (ed. M. Horvat): 143-148. October 14-16, 2010, Šibenik, Croatia.

Fairbanks R.G. (1989) A 17,000 year glacio-eustatic sea level record: influence of glacial melting rates on the Younger Dryas event and deep-ocean circulation. Nature, 342: 637-642.

Frignani M., Langone L. (1991) Accumulation rates and ${ }^{137} \mathrm{Cs}$ distribution in sediments of the Po River delta and the Emilia-Romagna coast (northwestern Adriatic Sea, Italy). Continental Shelf Research, 11: 525-542.

Gensous B., Williamson D., Tesson M. (1993) Late-Quaternary transgressive and highstand deposits of a deltaic shelf (Rhone delta, France). IAS Special Publications, 18: 197-211.

Gotovac H., Bojanić D., Vranješ M., Jović V., Andričević R. (2003) Prodor mora u aluvij donje Neretve (Intrusion of sea into the lower Neretva alluvium - in Croatian). Proceedings of 3th Croatian conference about waters "Hrvatske vode u 21. stoljeću” (ed. D. Gereš): 247-254. May 28-31, 2003, Osijek, Croatia.

Kalac K. (2008) Biostratigrafsko-kronostratigrafska istraživanja pliocensko-pleistocenskih naslaga u podmorju Jadrana $\mathrm{s}$ posebnim osvrtom na klimatske promjene (Biostratigraphic and chronostratigraphic explorations of Pliocene-Pleistocene sediments in the Adriatic with special review of the climate changes - in Croatian). Naftaplin, book 45 (8).

Marini M., Grilli F., Guarnieri A., Jones B.H., Klaic Z., Pinardi N., Sanxhaku M. (2010) Is the southeastern Adriatic Sea coasta strip and eutrophic area? Estuarine, Coastal and Shelf Science, 88 (3): 395-406.

Milliman J.D., Syvitski J.P.M. (1992) Geomorphic/tectonic control of sediment discharge to the ocean: the importance of small mountainous rivers. Journal of Geology, 100: 525-544.

Prelogović E., Kranjec V. (1983) Geološki razvitak područja Jadranskog mora. Pomorski zbornik, 21: 387-405.

Rio D., Channel J.E.T., Bertoldi R., Poli M.S., Vergerio P.R., Raffi I., Sprovieri R., Thunell R.C. (1997) Pliocene sapropels in the northern Adraiatic area: chronology and paleoenvironmental significance. Palaeogeography, Palaeoclimatology, Palaeoecology, 135: 1-25.

Sondi I., Juračić M., Pravdić V. (1995) Sedimentation in a disequilibrium river-dominated estuary. The Raša River Estuary (Adriatic Sea-Croatia). Sedimentology, 42: 769-782.

Sorgente D. (1999) Studio della sedimentazione attuale e recente nel medio Adriatico attraverso l'uso di traccianti radioattivi. Dissertation, University of Bologna.

Thunel M. (1971) Grada tercijarnog bazena u sjeveroistočnom dijelu Jadranskog mora (Settings of the Tertiary basin in the north-eastern part of the Adriatic Sea - in Croatian). Nafta, 22 (4-5): 275-434.

Trincardi F., Cattaneo A., Correggiari A. (2004) Mediterranean prodelta systems. Oceanography, 17 (4): 35-45.

Van Straaten L.M.J.U. (1964) Turbidite Sediments in the Southern Adriatic Sea. Developments in Sedimentology, 3: 142-147.

Velić J. (2007) Geologija ležišta nafte i plina (Geology of oil and gas reservoirs - in Croatian), first ed. University of Zagreb, Faculty of Mining, Geology and Petroleum Engineering, Zagreb.

Velić J., Malvić T. (2011) Depositional conditions during Pliocene and Pleistocene in Northern Adriatic and possible lithostratigraphic division of these rocks. Nafta, 62 (1-2): 33-38.

Velić J., Velić I., Kljajo D. (2011) Sedimentary bodies, forms and occurences in the Tudorevo and Mirovo glacial deposits of northern Velebit (Croatia). Geologia Croatica, 64 (1): 1-16.

Veseli V. (1999) Facijesi karbonatnih sedimenata mlađeg mezozoika i paleogena u pučinskim bušotinama sjevernog Jadrana (Late Mesozoic and Palaeogene carbonate facies in the off-shore wells in the northern Adria - in Croatian). Dissertation, University of Zagreb, Faculty of Mining, Geology and Petroleum Engineering, Zagreb.

Vlahović I., Tišljar J., Velić I. and Matičec D. (2005) Evolution of the Adriatic Carbonate Platform: palaeogeography, main events and depositional dynamics. Palaeogeography, Palaeoclimatology, Palaeoecology, 220 (3-4): 333-360.

Wilkinson B.H., Byrne J.R. (1977) Lavaca Bay - transgressive deltaic sedimentation in Central Texas estuary. AAPG Bulletin, 61 (4): 527-545. 